\title{
IN VITRO ANTIPLASMODIAL ACTIVITY OF COUMARIN 8-HYDROXYISOCAPNOLACTONE-2', 3'-DIOL ISOLATED FROM Micromelum minutum (G. Forst.) Wight \& Arn
}

\author{
Ratna Asmah Susidarti ${ }^{1} *$, Mustofa ${ }^{2}$, Vivanty Pemi Lusika ${ }^{1}$, Yoseph Novi Astana ${ }^{1}$
}

\begin{abstract}
1 Dept. of Pharmaceutical Chemistry, Faculty of Pharmacy, Univ. Gadjah Mada, Yogyakarta 55281, Indonesia.

2Dept. of Pharmacology and Therapy, Faculty of Medicine, Univ. Gadjah Mada, Yogyakarta 55281, Indonesia.
\end{abstract}

Submitted: $12-08-2013$

Revised: 09-11-2013

Accepted: $19-12-2013$

*Corresponding author Ratna Asmah Susidarti

Email :

ratnasusidarti@ymail.com

\begin{abstract}
Malaria remains a health problem in tropical and subtropical countries. The spread of antimalarial resistant parasites has prompted the research to find more effective new antimalarials. One strategy to discover new antimalarial drugs is through the exploration of medicinal plants traditionally used to treat malaria. Micromelum minutum is one of medicinal plants has been used to treat malaria and other infectious diseases in Malaysia. The coumarin 8-hydroxyisocapnolactone-2', $3^{\prime}$-diol has been isolated from this plant and showed to have strong cytotoxic activities. This study aimed to evaluate the in vitro antiplasmodial activity of 8hydroxyisocapnolactone-2', $3^{\prime}$-diol against chloroquine-resistant (FCR-3) and chloroquine-sensitive (D-10) Plasmodium falciparum. Culture of $P$. falciparum was continuously grown using a candle jar. Antiplasmodial assay was conducted by microradioactive method. The antiplasmodial activity was expressed by the $\mathrm{IC}_{50}$ indicating the concentration of the compound yielding $50 \%$ inhibition of the parasit growth. The results showed that 8-hydroxyisocapnolactone$2^{\prime}, 3^{\prime}$-diol has in vitro antiplasmodial activity against FCR-3 and D-10 with the $\mathrm{IC}_{50}$ values of $6.39 \mu \mathrm{g} / \mathrm{mL}(16.99 \mu \mathrm{M})$ and $24.23 \mu \mathrm{g} / \mathrm{mL}$ $(64.45 \mu \mathrm{M})$, respectively.
\end{abstract}

Key words: 8-hydroxyisocapnolactone-2', $3^{\prime}$-diol, $M$. minutum, antiplasmodial activity, P. falciparum, FCR-3, D-10

\section{INTRODUCTION}

Malaria remains a serious public health problem in tropical and subtropical countries. In 2010, it was estimated that 219 million cases of malaria occurred worldwide and lead to 660.000 deaths (CDC, 2012). According to the World Health Organization (WHO), in 2011 approximately 3,3 billion people live in areas with high risk of malaria (WHO, 2012). In Indonesia, it was estimated that $45 \%$ of the population live in areas at risk of malaria transmission (Ministry of Health of the Republic of Indonesia, 2010). Almost all provinces in Indonesia have malaria-endemic areas with different level of endemicity. Areas with high malaria endemicity are located outside the Java island, such as Maluku, Papua, Nusa Tenggara, Sulawesi, Borneo and Sumatra. In 2009 1,100,000 cases of clinical malaria have been reported in Indonesia and it increased to $1,800,000$ cases in 2010 (Ministry of Health of the Republic of Indonesia, 2011).
Although malaria eradication program has been conducted to eliminate malaria, however its prevalence remains high. Antimalarial drug resistance to Plasmodium has emerged as one of the cause of malaria eradication failures. The extensive and rapid spread of parasites resistance to antimalarials, especially chloroquine, and the limited antimalarial drugs in the market have driven the need to find new antimalarial drugs. One of strategies in new antimalarials discovery is through the exploration of medicinal plants traditionally used to treat malaria.<smiles>C=C1C=C(C=CC(C)(O)C(O)COc2ccc3ccc(=O)oc3c2O)OC1=O</smiles>

Figure 1. 8-Hydroxyisocapnolactone-2' 3 '-diol

Micromelum minutum has been used to treat malaria as well as other infectious diseases 
in Malaysia (Burkill, 1966). The coumarin 8hydroxyisocapnolactone-2', $3^{\prime}$-diol (Figure 1) has been isolated as the main constituent of this plant that grows in Sabah, Malaysia (Rahmani et al., 2003). This compound has been reported to have strong cytotoxic activity against CEM-SS, HL60, HeLa, HepG2, and NS-1 cancer cell lines (Susidarti et al., 2009; Yasmina et al., 2005). However, the antiplasmodial activity of this compound has never been studied, yet. This study aimed to evaluate the in vitro antiplasmodial activity of 8-hydroxyisocapnolactone-2' $3^{\prime}$-diol against chloroquine-resistant (FCR-3) and chloroquin-sensitive (D-10) $P$. falciparum.

\section{MATERIAL AND METOHODS}

8-Hydroksyisocapnolactone-2' 3 '-diol used in this study was obtained from Dr. Ratna Asmah Susidarti, Faculty of Pharmacy, Gadjah Mada University. The compound was isolated from the chloroform extract of the leaves of $M$. minutum by Rahmani et al. (2003). Strains of $P$. falciparum FCR-3 (chloroquin-resistant) and D10 (chloroquin-sensitive) were obtained from the Eijkman Institute for Molecular Biology, Jakarta. Other chemicals used in the antiplasmodial assay were RPMI 1640 (Gibco), HEPES (Sigma), gentamicin (Merck), $\mathrm{NaHCO}_{3}$ (Sigma), sorbitol (Merck), Giemsa (Sigma), sterile aquabidest, $\mathrm{NaOH}$ 0,1 M, human serum group $0+$, human blood cells group $0+$, ethanol $70 \%$ (technical grade), methanol, $\left(2,8{ }^{3} \mathrm{H}\right)$ hypoxanthine isotope (Sigma) and betafluor for scintillation (Packard).

\section{Continuous culturing of $\boldsymbol{P}$. falciparum Thawing of $P$. falciparum}

Ampoules containing $P$. falciparum FCR-3 and D-10 strains were removed from liquid nitrogen, placed in water bath at $37^{\circ} \mathrm{C}$ until the blood was fully thawed and then transfered to conical tube. As many as $0.2 \mathrm{~mL}$ of $12 \% \mathrm{NaCl}$ solution was added drop by drop for every $1 \mathrm{~mL}$ thawed blood. The solution was mixed and allowed to stand for $3 \mathrm{~min}$. Ten milliliters of $1.6 \% \mathrm{NaCl}$ solution was added drop by drop for every $1 \mathrm{~mL}$ of thawed blood. The solutions was sentrifuged at $1500 \mathrm{rpm}$ for $5 \mathrm{~min}$ and then the supernatant was removed. Ten milliliters of a mixture of $0.9 \% \mathrm{NaCl}$ and $0.2 \%$ dextrose solution was added for each $1 \mathrm{~mL}$ thawed blood. This solution was centrifuged again at $1500 \mathrm{rpm}$ for $5 \mathrm{~min}$ and the supernatant was removed. The precipitated cells were slowly resuspended in complete medium containing human serum and then incubated for $48 h$.

\section{Culturing $P$. falciparum}

Plasmodium falciparum was cultured using a candle jar method developed by Trager and Jensen (1976). Parasite-infected erythrocytes were cultured in a culture flask containing $10 \mathrm{~mL}$ of complete medium (containing 10\% serum) to a final hematocrit of $1.5 \%$. Manipulation of the culture was performed in a laminar air flow cabinet under aseptic conditions. The Plasmodium culture was then placed in the $\mathrm{CO}_{2}$ incubator at $37^{\circ} \mathrm{C}$.

\section{Maintaining culture}

The Plasmodium culture was maintained by replacing the media every $24 \mathrm{~h}$ of incubation. When the parasitemia was too high $(>10 \%)$, subculture should be made by adding normal red blood cells until the parasitaemia $<1 \%$.

\section{Sample Preparation}

Five milligrams of 8-Hydroxyisocapnolactone-2' $3^{\prime}$-diol was dissolved in $100 \mu \mathrm{L}$ of DMSO and added to RPMI 1640 medium to obtain the volume of $5.0 \mathrm{~mL}$ as a stock solution. This solution was then diluted with RPMI 1640 to obtain a series of concentrations of $10 ; 25$; 50; 100; and $150 \mu \mathrm{g} / \mathrm{mL}$.

\section{Synchronization}

Malaria parasites undergo various stages of growth within erythrocytes, namely young trophozoit (ring stage), trophozoit, and finally schizont. For antiplasmodial activity testing, the ring stage parasites were used after synchronized with $5 \%$ sorbitol solution. Parasites were centrifuged at $1500 \mathrm{rpm}$ for $10 \mathrm{~min}$. Supernatant was removed and the precipitate was soaked in a sterile $5 \%$ sorbitol solution as many as $5 \mathrm{x}$ volume of supernatan and then allowed to stand at room temperature for $10 \mathrm{~min}$. During this period, schizont stage parasites have been lysed and leave the tropozoit stage. With additional of $5 \mathrm{x}$ volume of complete medium, the parasite was then 
washed by centrifugation at $1500 \mathrm{rpm}$ for $10 \mathrm{~min}$. The precipitated parasite that only consists of a ring stage was obtained. The parasite was then returned to the culture flask. Synchronization was carried out every $48 \mathrm{~h}$ to obtain the more homogeneous ring-stage parasites.

\section{Preparation of microcultures and antiplasmodial activity assay (Rieckman et al., 1978).}

The 96 wells microplate was used to culture the parasites Each well was filled with $100 \mathrm{~mL}$ of complete medium containing parasites with 1.5\% hematocrit and $1 \%$ parasitemia. The test solutions were prepared in sterile bottles, and by using a $100 \mu \mathrm{L}$ micropipette, each solution was transferred into the wells ranging from low to high concentrations, whereas $100 \mu \mathrm{L}$ RPMI 1640 solution was added into the untreated group. Each concentration was made triplicate. Microculture plate was then placed in a vacuum desiccator containing a candle in it (candle jar). The desiccator was covered when the candle flame almost die, so that the optimal concentration of gas was available for the culture. The jar was then incubated in a $\mathrm{CO}_{2}$ incubator at $37^{\circ} \mathrm{C}$ for $60 \mathrm{~h}$.

\section{Examination of microradioactive methods (Desjardins et al., 1979).}

Preparation of $\left(2,8-{ }^{3} \mathrm{H}\right)$ hypoxanthine solution

$\left(2,8-{ }^{3} \mathrm{H}\right)$ hypoxanthine was used as a marker of parasite growth. The amount of isotopes used by parasites can be measured that represented the magnitude of parasite growth in culture. The isotope was supplied in ampoules containing $1.0 \mathrm{mCi}$. A total of $20 \mu \mathrm{L}$ isotope was diluted with RPMI 1640 containing $10 \%$ human serum to a volume of $4.0 \mathrm{~mL}$ to obtain a solution that has a radioactivity of 0.25 $\mu \mathrm{Ci}$ per $50 \mu \mathrm{L}$.

\section{Addition of hypoxanthine isotopes into} microcultures

After $60 \mathrm{~h}$ incubation period and the culture growth healthily without contamination, $50 \mu \mathrm{L}$ hypoxanthine isotope was added to each well. The culture was homogeneously mixed by shaking it on the table, then returned to the candle jar and incubated at $37^{\circ} \mathrm{C}$ for $12 \mathrm{~h}$ to obtain a $72 \mathrm{~h}$ incubation period.
Harvesting parasites and counting in $\beta$ counter

Harvester was arranged so that the radioactive content of each well will be caught in the strainer filters. The filter was previously moistened with $0.9 \%$ saline solution. This filter was then washed with sterile aquabidest for $20 \mathrm{~s}$ to lyse erythrocytes and wash the hemoglobin. The filter was then dried in an oven at $60^{\circ} \mathrm{C}$. The sphere part of the filter was moved into counting vials. Those vials was then filled with $0.5 \mathrm{~mL}$ of liquid scintillation betafluor and put in a Liquid Scintillation Analyzer. Counting efficiency is approximately $30 \%$. The Print out of the isotope usage from $\beta$ counter calculation result was read on three different zones and expressed in counts per minute (cpm). The number of isotopes used represented the growth of parasite. The percentage of parasite growth inhibition can be calculated by the following formula:

$\%$ inbibition $\frac{c p m \text { control }-c p m \text { sample }}{c p m \text { control }} \times 100 \%$

\section{Analysis}

The result was shown as the relationship curve between the concentration of 8hidroxyisocapnolactone-2', $3^{\prime}$-diol and $\%$ inhibition of Plasmodium growth. Inhibitory Concentration fifty percent of parasite growth $\left(\mathrm{IC}_{50}\right)$ value was determined by probit analysis according to the relation of $\log$ concentration of test compound and \% inhibition of parasite growth.<smiles>[1H]c1nc2[nH]c(P)nc2c(=O)[nH]1</smiles>

Figure 2. Structure of $\left(2,8-{ }^{3} \mathrm{H}\right)$ hypoxanthine isotope

\section{RESULT AND DISCUSSION}

Plasmodium falciparum proliferation requires large amounts of purine. In the absence of de novo purine biosynthesis in the parasite, hence the need of purines was obtained from the environment. Purine bases released by the hydrolytic degradation of nucleic acids and nucleotides can be salvaged 
Table I. Inhibition of the growth (\%) of chloroquine-resistant P. falciparum (FCR-3) due to administration of 8 -hydroxyisocapnolactone-2'3'-diol on the three measurement zones

\begin{tabular}{ccccc}
\hline \multirow{2}{*}{$\begin{array}{c}\text { Concentration } \\
(\boldsymbol{\mu g} / \mathbf{m L})\end{array}$} & \multicolumn{4}{c}{ \% inhibition } \\
\cline { 2 - 5 } & Zona 0-3 keV (A) & Zona 0-5 keV (B) & Zona 0.5-8 keV (C) & mean $\mathbf{\text { 0 SD }}$ \\
\hline 50 & 98.76 & 98.83 & 98.81 & $98.80 \pm 0.04$ \\
5 & 21.64 & 21.87 & 22.15 & $21.89 \pm 0.26$ \\
1 & 11.72 & 13.06 & 14.21 & $13.00 \pm 1.25$ \\
0.5 & 9.00 & 14.25 & 17.10 & $13.45 \pm 4.11$ \\
0.1 & 7.13 & 7.96 & 8.70 & $7.93 \pm 0.79$ \\
0.05 & 8.88 & 10.30 & 10.87 & $9.99 \pm 1.07$ \\
\hline
\end{tabular}

Table II. Inhibition of the growth (\%) of chloroquine-sensitive P. falciparum (D-10) due to administration of 8 -hydroxyisocapnolactone-2' $3^{\prime}$-diol on the three measurement zones

\begin{tabular}{ccccc}
\hline Concentration & \multicolumn{5}{c}{ \% inhibition } \\
\cline { 2 - 5 }$(\boldsymbol{\mu g} / \mathbf{m L})$ & Zona 0-3 keV (A) & Zona 0-5 keV (B) & Zona 0,5-8 keV (C) & mean $\mathbf{~ S D ~}$ \\
\hline 150 & 98.17 & 98.05 & 97.92 & $98.05 \pm 0.12$ \\
100 & 97.59 & 97.27 & 97.00 & $97.29 \pm 0.29$ \\
50 & 94.46 & 94.48 & 94.34 & $94.43 \pm 0.07$ \\
25 & 62.67 & 62.40 & 60.70 & $61.92 \pm 1.07$ \\
10 & 0.00 & 0.00 & 0.00 & 0.00 \\
\hline
\end{tabular}

and recycled by the parasites. Hypoxanthine is a precursor of purine salvage pathway. In the Plasmodium cell, hypoxanthine will be metabolized into inosine monophosphate (IMP). Through a series of chemical and enzymatic processes IMP will be converted to RNA and DNA adenine and guanine bases (Berrens et al., 1995). The existence of a large Number of $\left(2,8-{ }^{3} \mathrm{H}\right)$ hypoxanthine isotopes (Figure 2) and the presence of a small number of purine bases and nucleosides in the medium, a number of isotopes will be taken and metabolized by the parasite. Therefore, by measuring the radioactivity of $\left(2,8-{ }^{3} \mathrm{H}\right)$ hypoxanthine isotopes have been taken by parasites, the number of alive parasites can be determined.

Treatment of 1, 5 and $50 \mu \mathrm{g} / \mathrm{mL} 8$ hydroxyisocapnolactone-2'3'-diol on chloroquine resistant $P$. falciparum (FCR-3) showed a dose-dependent profile in all three measurement zones (Table I). Observation on the three zones showed that the percentage of growth inhibition of the parasites was increased along with the increasing levels of the test compound. The same phenomenon was also observed on the D-10 strain treated with 25 and $50 \mu \mathrm{g} / \mathrm{mL}$ of the coumarin (Table II). The graph showing the relationship between the concentration of test compound with the average of $\%$ growth inhibition of $P$. falciparum FCR-3 and D - 10 can be seen in Figure 3 and 4, respectively.

Antiplasmodial activity was expressed as the $\mathrm{IC}_{50}$ value and determined by probit analysis. The $\mathrm{IC}_{50}$ values of 8-hydroxyisocapnolactone-2' 3 '-diol against $P$. falciparum D-10 and FCR-3 strains in all three measurement zones can be seen in Table III. The 8-hydroxyisocapnolactone-2' $3^{\prime}$-diol was found to be significantly active against chloroquine resistant and sensitive strains of $P$. falciparum with $\mathrm{IC}_{50}$ of $6.39 \mu \mathrm{g} / \mathrm{mL} \quad(16.99 \mu \mathrm{M})$ and $24.23 \mu \mathrm{g} / \mathrm{mL} \quad(64.45 \mu \mathrm{M})$, respectively. The antiplasmodial activity of 8-hydroxyisocapnolactone-2'3'-diol against chloroquine-resistant strain was stronger than chloroquine-sensitive strain. Based on this finding, this compound was expected to have different mechanism of action with chloroquine. The mechanism of action of chloroquine as antiplasmodial related to its ability to inhibit polymerization and detoxification of heme, the ability to bind and 


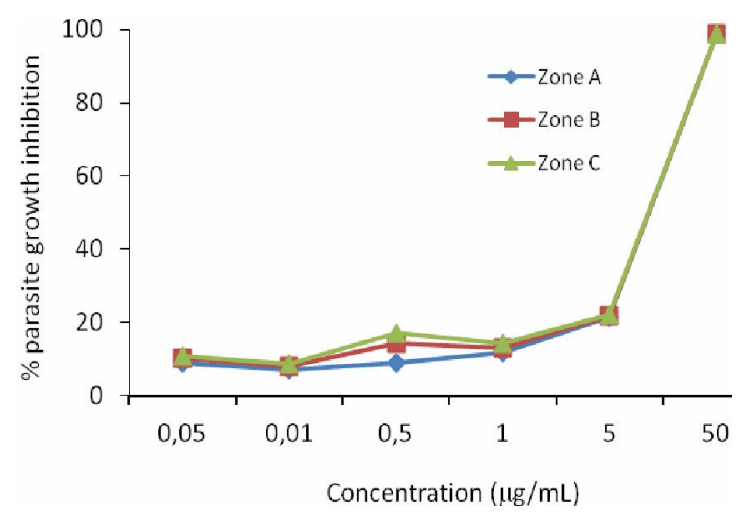

Figure 3. Graph between the concentration of 8-hydroxyisocapnolactone-2' $3^{\prime}$-diol versus \% inhibition of the growth of chloroquine-resistant P. falciparum (FCR-3) (FCR-3) on the three measurement zones $(\mathrm{A}=0-3 \mathrm{keV} ; \mathrm{B}=0-5 \mathrm{keV} ; \mathrm{C}=0.5-8 \mathrm{keV})$

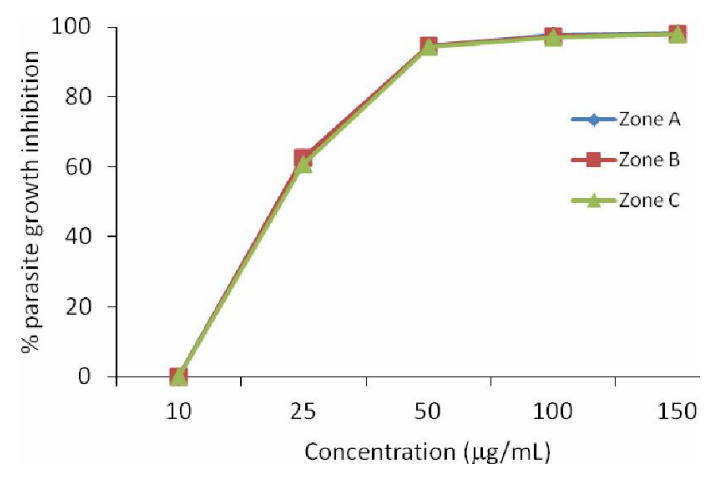

Figure 4. Graph between the concentration of 8-hydroxyisocapnolactone-2'3'-diol versus \% inhibition of the growth of chloroquine-sensitive $P$. falciparum (D-10) on the three measurement zones $(\mathrm{A}=0-3 \mathrm{keV} ; \mathrm{B}=0-5 \mathrm{keV} ; \mathrm{C}=0.5-8 \mathrm{keV})$

alter the nature of DNA, and the weak base properties of chloroquine allowed a high accumulation of this compounds in Plasmodium cell (Ahmad and Sutanto, 2003).

8-Hydroxyisocapnolactone-2' ${ }^{\prime}$ '-diol has the same basic chemical structure as 7,8dihydroxycoumarin (daphnetin), but has a side chain attached to oxygen atom at C-7. The side chain consists of alkyl group containing $5 \mathrm{C}$ atoms with 2 hydroxyl groups at C-2' and C-3' and a $\gamma$-lactone ring substituted by methylene at position 4". Daphnetin was first isolated from Daphne sp. The compounds with similar structure will usually shown a similar biological activity. Both of these coumarins have antiplasmodial activity. The $\mathrm{IC}_{50}$ values of dafnetin on $P$. falciparum in vitro was 4.45$7.12 \mu \mathrm{g} / \mathrm{mL}(25-40 \mu \mathrm{M})$.
Daphnetin was able to decrease the activity of superoxide dismutase (SOD) by $60 \%$ and inhibited the synthesis of DNA on $P$. falciparum in vitro (Mu, et al., 2003). SOD is an enzyme that catalyze the reaction of the superoxide $(\mathrm{O} 2 \cdot *)$ to hydrogen peroxide $\left(\mathrm{H}_{2} \mathrm{O}_{2}\right)$ and oxygen $\left(\mathrm{O}_{2}\right)$ in the presence of acid, according to the reaction of $2 \mathrm{O}_{2} \cdot+2 \mathrm{H}^{+} \rightarrow$ $\mathrm{H}_{2} \mathrm{O}_{2}+\mathrm{O}_{2}$. This was a spontaneous reaction, but the reaction rate is stimulated by the presence of SOD. Superoxide together with hydrogen peroxide $\left(\mathrm{H}_{2} \mathrm{O}_{2}\right)$, peroxy radicals (ROO') and hydroxyl radical $\left(\mathrm{OH}^{\circ}\right)$ were strong oxidator produced in the metabolism process in the cells. The oxygen has been played an important role in the injury or damage of the cells (Murray, 2003). Even though it seemed to be less dangerous than hydroxyl radical, but 
Table III. IC 50 value of 8-hydroxyisocapnolactone-2'3'-diol of chloroquine-resistant (FCR-3) and chloroquine-sensitive (D-10) P. falciparum on the three measurement zones

\begin{tabular}{ccc}
\hline \multirow{2}{*}{ Measurement Zones $(\mathbf{k e V})$} & \multicolumn{2}{c}{$\mathbf{I C}_{50}(\boldsymbol{\mu g} / \mathbf{m L})$} \\
\cline { 2 - 3 } & FCR-3 & D-10 \\
\hline $0-3$ & 6.91 & 24.03 \\
$0-5$ & 6.31 & 24.14 \\
$0.5-8$ & 5.94 & 24.53 \\
mean \pm SD & $6.39 \pm 0.4895$ & $24.23 \pm 0.26$ \\
\hline
\end{tabular}

superoxide was more reactive than hydrogen peroxide in physiologic system (Halliwell and Gutteridge, 1999). Inhibition of SOD resulted in increasing the amount of superoxide in the parasites. One other species, $\mathrm{HO}_{2}{ }^{\circ}$, which was a protonated superoxide and slightly more reactive than superoxide itself. $\mathrm{HO}_{2}$. formed at acidic $\mathrm{pH}$ near the membrane may caused severe harm as a result of fatty acid peroxidation (Halliwell and Gutteridge, 1999). Superoxide in large quantities can lead to injury and even cells death (Murray, 2003).

Other study showed that daphnetin decrease the DNA synthesis of $P$. falciparum in vitro (Yang et al., 1992). DNA synthesis occurs in the mitotic process. During this process, all the nucleus DNA is replicated and then the cells was replicated. DNA is involved in the synthesis of protein where the genes in DNA control the synthesis of various types of RNA associated with the protein synthesis. The decrease in DNA synthesis, parasite replication is inhibited, so the parasites will die due to lack of proteins that play an important role in the metabolic processes in the parasite. The inhibition of DNA synthesis at various growth stages of $P$. falciparum by daphnetin has been carried out on the synchronized culture. The result showed that daphnetin inhibits DNA synthesis of $P$. falciparum on tropozoit stage. Based on the similarity in basic chemical structure with daphnetin, it was estimated that the mechanism of antiplasmodial activity of 8hydroxyisocapnolactone-2' 3 '-diol was through the inhibition of SOD activity and the DNA synthesis of the parasit.

Scopoletin (7-hydroxy,6-metoxycoumarin) which did not have a hydroxyl group at C-8 apparently did not show in vitro antiplasmodial activity (Yang et al., 1992). Based on this report, it was estimated that the hydroxyl group at C-8 is responsible for the antiplasmodial activity of coumarin derivatives. It could be expected that the hydroxyl group at C-7 contributed to the antiplasmodial activity although it was not as strong as the hydroxyl group at C-8 position. This was supported by the fact that the 8hydroxyisocapnolactone-2' 3 '-diol containing substituted hydroxyl group at C-7 position still has good activity. The antiplasmodial activity of 8-hydroxyisocapno-lactone-2' 3 '-diol against $P$. Falciparum provides a scientific evidence regarding the usefulness of $M$. minutum as an antimalarial. The result of this study is expected to be utilized in the development of antimalarial drugs.

\section{CONCLUSION}

8-Hydroxyyisocapnolactone-2'3'-diol isolated from $M$. minutum has in vitro antiplasmodial activity against P. falciparum FCR-3 and D-10 strains with $\mathrm{IC}_{50}$ values of $6.39 \mu \mathrm{g} / \mathrm{mL} \quad(16.99 \mu \mathrm{M})$ and $24.23 \mathrm{mg} / \mathrm{mL}(64.45 \mu \mathrm{M})$, respectively.

\section{ACKNOWLEDGEMENTS}

The authors thank to QUE Project Faculty of Pharmacy for financial support and Parasitology Laboratory of the Faculty of Medicine, Gadjah Mada University and National Atomic Energy Agency for providing the facilities.

\section{REFERENCES}

Achmad MF. and Sutanto, I., 2003, Peran gen pfmdr-1 pada mekanisme resistensi Plasmodium falciparum terhadap klorokuin, Majalah Kedokteran Indonesia, 53(2), 72.

Berrens RB., Krug CE., and Marr J., 1995, Purine dan pyrimidine metabolism. In: 
Marr JJ. and Muller M. (Ed.), Biochemistry and molecular biology of parasite, Academic Press Limited, London, pp. 89-91.

Burkill IH., 1966, A dictionary of economic products of the Malay Peninsula. In: Crown agents for the Colonies, London, Ministry of Agriculture and Cooperatives, Kuala Lumpur, Reprinted, pp. 1492-1493.

Centers for Disease Control and Prevention (CDC), 2012, Malaria. http://www.cdc. gov $/ \mathrm{malaria} / \mathrm{html}$. Accessed on November $15^{\text {th }} 2013$.

Desjardins RE., Canfield CJ., Haynes JD. dan Chulay JD., 1979, Quantitative assessment of antimalarial activity in vitro by a semiautomated microdilution technique. Antimicrob. Agents Chemother., 16, 710-718.

Halliwell B. and Gutteridge JMC., 1999, Free Radicals in Biology dan Medicine, 3rd ed, Oxford University Press, New York, pp. 129-130.

Ministry of Health of The Republic of Indonesia, 2010, Bersama kita berantas malaria, Jakarta.

Ministry of Health of The Republic of Indonesia, 2011, Pengendalian malaria masih hadapi tantangan, Jakarta.

Mu LY., Wang QM., Ni YC., 2003, Effect of daphnetin on SOD activity dan DNA synthesis of Plasmodium falciparum in vitro, Zhongguo Ji Sheng Chong Xue Ji Sheng Chong Bing Za Zhi, 21(3):157-159.

Murray RK. 2003, Red \& White Blood Cells. In: Murray, R.K., Granner D.K., Mayes P.A., Rodwell V.W. (Ed.), Harper's
Illustrated Biochemistry. 26 th ed. Mc GrawHill Companies Inc, USA, pp. 609-613.

Rahmani M., Susidarti RA., Ismail HBM., Sukari, MA., Taufik-Yap, YH., Gwendolin-Ee, CL., Ali, AM., Kulip, J., and Waterman, PG, 2003, Coumarins from Malaysian Micromelum minutum, Phytochemistry, 64, 873-877.

Rieckman KH., Campbell GH., Sax LJ., Mrema JE. 1978, Drug sensitivity of Plasmodium falciparum, an in vitro microtechnique, Lancet, 7, 22-23.

Susidarti RA., Mawardi R., Ismail HBM., Sukari MA., Taufik-Yap YH., Gwendolin-Ee, CL., Ali AM., Kulip J., and Waterman PG. 2009, Cytotoxic activity of coumarins from Micromelum minutum, Pharmacentical Biology, 47(2), 182-183.

Trager W. dan Jensen JB., 1976, Human Malaria Parasite in Continous Culture, Science, 193, 673-675.

WHO, 2012, World Malaria Report 2012, Geneva. http://www.who.int/malaria/world_mal aria_report_2011/en/. Accessed on July 13 th 2013, p.1

Yang YZ., Ranz A., Pan HZ., Zhang ZN., Lin, XB., and Meshnick SR, 1992, Daphnetin : a novel antimalarial agent with in vivo activity. Am.J. Trop. Hyg, 46(1), 15-20.

Yasmina A., Mustofa and Susidarti RA., 2005, Kumarin 8-hidroksiisokapnolakton-2', $3^{\prime}$ diol dari daun Micromelum minutum: Aktivitas sitotoksik dan efeknya terhadap ekspresi Bcl-2 sel myeloma, Sains Kesehatan, 18(4), 517-529. 